\title{
Receptors and Lethal Effect of Bacillus thuringiensis Insecticidal Crystal Proteins to the Anticarsia gemmatalis (Lepidoptera, Noctuidae)
}

\author{
Lidia Mariana Fiuza, ${ }^{1}$ Neiva Knaak, ${ }^{1}$ Rogério Fernando Pires da Silva, ${ }^{2}$ \\ and João Antônio Pêgas Henriques ${ }^{3}$ \\ ${ }^{1}$ UNISINOS, Área 2, Laboratório de Microbiologia e Toxicologia, Avenida Unisinos 950, 93022 São Leopoldo, RS, Brazil \\ ${ }^{2}$ UFRGS, Fitossanidade, Porto Alegre, RS, Brazil \\ ${ }^{3}$ UFRGS, Biotecnologia, Porto Alegre, RS, Brazil \\ Correspondence should be addressed to Lidia Mariana Fiuza; fiuza@unisinos.br
}

Received 29 July 2013; Accepted 28 August 2013

Academic Editors: J. Maupin-Furlow and T. P. West

Copyright ( $) 2013$ Lidia Mariana Fiuza et al. This is an open access article distributed under the Creative Commons Attribution License, which permits unrestricted use, distribution, and reproduction in any medium, provided the original work is properly cited.

\begin{abstract}
Bioassays with insecticidal crystal proteins (ICPs) from Bacillus thuringiensis have demonstrated that CrylAa, CrylAc, and CrylBa are the most active toxins on larvae of the Anticarsia gemmatalis. The toxins CrylDa and CrylEa are less toxic, and toxins Cry2Aa are not active. Binding of these ICPs to midgut sections of the A. gemmatalis larvae was studied using streptavidin-mediated detection. The observed staining patterns showed that CrylAa and CrylAc bound to the brush border throughout the whole length of the midgut. However, the binding sites of CrylBa were not evenly distributed in the midgut microvilli. The in vivo assays against larvae of 2 nd instar A. gemmatalis confirmed the results from the in vitro binding studies. These binding data correspond well with the bioassay results, demonstrating a correlation between receptors binding and toxicity of the tested ICPs in this insect.
\end{abstract}

\section{Introduction}

Bacillus thuringiensis is one of the most widely used microorganisms for the biological control of insects [1-3]. This gram-positive spore-forming bacterium characteristically produces crystals containing one or several insecticidal crystal proteins-ICPs [4-7]. A novel nomenclature has been proposed based exclusively on amino acid identity. Currently, more than 560 cry genes have been identified and classified into 68 classes based on the homology of their proteins (http://www.lifesci.sussex.ac.uk/home/Neil_Crickmore/Bt). The cry genes code for proteins with a range of molecular masses from 50 to $140 \mathrm{kDa}[8,9]$. Lepidopteran-specific ICPs are typically produced as bipyramidal crystals that are solubilized in the often alkaline environment ( $\mathrm{pH} 10$ to 12 ) of the larval midgut [10-13]. These proteins, belonging to the Cryl class of ICPs, are protoxins with a range of molecular masses from 130 to $140 \mathrm{kDa}[9,14]$ that are proteolytically activated by midgut proteases to toxic protease-resistant fragments ( 55 to $70 \mathrm{kDa}$ ) corresponding to the N-terminal half of the protoxin [14-16]. The delta-endotoxins bind with high affinity to proteins located in the midgut brush border membrane of susceptible insects [17-21]. Following the binding, the toxic fragment or a part of it inserts in to the membrane forming pores [22-24]. The formation of pores in the plasmatic membrane of the cells causes an ionic unbalance between the cytoplasm and the outside environment of the cell. The first effects are the stoppage of feeding and the paralysis of the gut, which causes the insect to die $[5,14,23,24]$.

Traditionally, the binding has been studied using native or biotinylated ICPs and midgut tissue sections [25, 26]. Using intoxicated insects, tissue sections can also be used to examine the histological effects of ICPs and their localization within the gut tract. Gross histological changes such as the enlargement of epithelial cells, the vacuolization of the cytoplasm, the hypertrophy or lyses of cells, and the disruption of the microvilli have been observed in the midgut using 
this technique [26-28]. Another type of binding site analysis using ligand blot demonstrated that the CrylAc toxin binds to a $120 \mathrm{kDa}$ protein in Manduca sexta [22,29]. This $120 \mathrm{kDa}$ protein was identified as aminopeptidase N [30]. Different insect proteins have been identified as receptors for cry proteins the $120 \mathrm{kDa}$ aminopeptidase $\mathrm{N}$ CrylAc toxin-binding protein purified from brush border vesicles of Manduca sexta, Heliothis virescens, and Lymantria dispar [30-34]. The CrylAa toxin binds a $120 \mathrm{kDa}$ protein-like aminopeptidase $\mathrm{N}$ [35] the $210 \mathrm{kDa}$ cadherin-like glycoprotein CrylAb toxin-binding protein purified from membranes of Manduca sexta and Ostrinia nubilalis [36,37].

Receptor binding has been demonstrated to be a key factor in the specificity of ICPs. Indeed, positive correlation between the toxicity and the binding to the brush border membrane $[19,21,25,38,39]$ has been found in many cases, although this correlation is not necessarily quantitative. An inverse correlation between the binding affinity and toxicity has been reported for Lymantria dispar [40]. It can be concluded that the binding is necessary but not sufficient for the toxicity. Specific binding involves two steps, one that is reversible and one that is irreversible. Other data suggest that toxicity correlates with irreversible binding [41]. Irreversible binding might be related to the insertion of the toxin into the membrane but could also reflect a tighter interaction of the toxin with the receptor [8]. For one species, different ICP types may bind to the same or to distinct receptors $[18,20,26,42-44]$.

The Anticarsia gemmatalis Hübner 1818 (Lepidoptera, Noctuidae) is one of the most important insect pests of soybean [45-47]. A. gemmatalis, also known as velvetbean caterpillar, attacks the plants hampering their development and thus causes losses in grain production $[47,48]$. The control of this pest can occur naturally under favorable conditions through the presence of natural enemies. When this does not happen, the use of insecticides with high applications per crop is designed to avoid loss in yield [49]. Currently, many adverse factors interfere in the velvetbean caterpillar control, such as the environmental impact that pesticides cause to other unrelated species and even to its natural enemies. The absence of data on the specificity of ICPs in A. gemmatalis enabled the realization of this paper, which analyzed the in vivo toxicity of different ICPs for $A$. gemmatalis and the presence of in vitro ICPs receptors in the midgut of this insect. The results should contribute to what is known about the toxicity of ICPs in A. gemmatalis, becoming an important tool in the management of the target insect.

\section{Materials and Methods}

2.1. B. thuringiensis ICPs. The cry proteins were obtained from a variety of sources including Pasteur Institut (IEBC, Paris, France) and Pant Genetics Systems (PGS, Ghent, Belgium): CrylAa: $B$. thuringiensis dendrolimus $\mathrm{HD} 37$ or from $B$. thuringiensis thuringiensis recombinant strain 407 (pHT408) (Kind gift of Dr. M.-M. Lecadet, Institut Pasteur, Paris, France); CrylAc: B. thuringiensis kurstaki HD73; CrylBa:

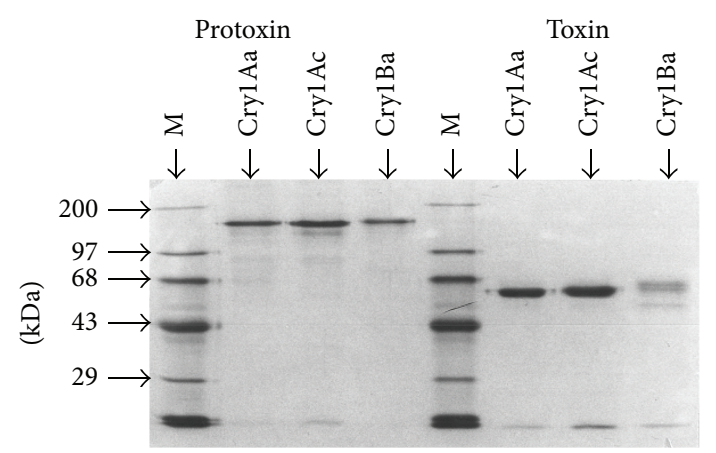

FIGURE 1: 10\% SDS polyacrylamide gel electrophoresis B. thuringiensis ICPs: CrylAa, CrylAc, and CrylBa protoxins and toxins (equal volumes $(2.5 \mu \mathrm{L})$ of protein activated (toxin) by incubation with bovine pancreatic trypsin (Type I; Sigma)), molecular mass markers (M).

B. thuringiensis thuringiensis 4412; CrylDa: B. thuringiensis aizawai HD68; CrylEa: B. thuringiensis darmstadiensis HD146, and Cry2Aa: was produced by a recombinant $B$. thuringiensis strain expressing the cry2Aa gene from $B$. thuringiensis kurstaki HD-1.

The B. thuringiensis strains were grown as described by Mahillon and Delcour [50]. The autolyzed culture was centrifuged and washed in a phosphate buffer $(100 \mathrm{mM}$ $\mathrm{NaH}_{2} \mathrm{PO}_{4}, 100 \mathrm{mM} \mathrm{NaCl}$, and $0.01 \%$ Triton X-100; $\mathrm{pH}$ 6). Crystals were separated from spores and debris using saccharose gradients ( 67 to $88 \% \mathrm{w} / \mathrm{v}$ ). The bands containing pure crystals were extensively washed and resuspended in distilled water containing $0.1 \mathrm{mM}$ phenylmethylsulfonyl (PMSF) and stored at $-20^{\circ} \mathrm{C}$. Crystal proteins were dissolved by incubation for $1 \mathrm{~h}$ at $37^{\circ} \mathrm{C}$ in an alkaline buffer $\left(50 \mathrm{mM} \mathrm{Na}_{2} \mathrm{CO}_{3}\right.$, $10 \mathrm{mM}$ dithiothreitol, and $0.1 \mathrm{mM}$ PMSF; $\mathrm{pH} 10$ ). The $\mathrm{pH}$ of the solution containing protoxins was adjusted to 8.6 by extensive dialysis against $20 \mathrm{mM}$ Tris, and the protoxins were activated by incubation with bovine pancreatic trypsin (Type I; Sigma) ( $1 \mu \mathrm{g}$ of per $20 \mu \mathrm{g}$ of protein) for $2 \mathrm{~h}$. The trypsin of the solution containing $\delta$-endotoxins was inactivated by adding $0.5 \mathrm{mg}$ trypsin inhibitor (Type II-S; Sigma) per mg of trypsin. The purity and integrity of deltaendotoxins samples were checked on a $10 \%$ sodium dodecyl sulfate-polyacrylamide gel [51] stained with Coomassie blue, according Figure 1. Protein concentrations were determined according to the method of Bradford [52] using bovine serum albumin (BSA) as a standard.

2.2. Insects and Bioassays. A. gemmatalis larvae were collected from soybean fields in Southern Brazil. The insects were maintained in the laboratory at $25 \pm 2^{\circ} \mathrm{C}, 12$ hours photoperiod, and $70 \%$ relative humidity $(\mathrm{RH})$, and the larvae were reared on an artificial diet described by Greene et al. [53]. The bioassays were performed on second instar larvae $\left(\mathrm{L}_{2}\right)$. The first step was established in a pilot test using $3 \cdot 10^{7}$ cells/mL by each strain. Five concentrations of the trypsinactivated B. thuringiensis ICPs (CrylAa, CrylAc, CrylBa, CrylDa, CrylEa, and Cry2Aa) were prepared in a phosphatesaline buffer (PBS: $10 \mathrm{mM} \mathrm{K}_{2} \mathrm{HPO}_{4}, 150 \mathrm{mM} \mathrm{NaCl}$; $\mathrm{pH}$ 7.4). 
Aliquots $(100 \mu \mathrm{L})$ were applied to the surface of the artificial diet in $9.6 \mathrm{~cm}^{2}$ petri dishes, and the larvae were placed in each petri dish. Three repeats per bioassay were performed using fifty larvae for each toxin concentration. In controls, the toxins were replaced by $100 \mu \mathrm{L}$ of PBS. Mortality was recorded after 7 days, and the results were analyzed by Probit analysis using Polo-PC Program LeOra Software, 1987 [54].

2.3. Biotinylation of ICPs. Activated ICPs were biotinylated according to the procedure [55, 56]. $40 \mu \mathrm{L}$ of biotinyl hydroxysuccinimide ester (Amersham) was added to $1 \mathrm{mg}$ of toxin dissolved in a sodium bicarbonate buffer $(100 \mathrm{mM}$ $\mathrm{NaHCO}_{3}, 150 \mathrm{mM} \mathrm{NaCl} ; \mathrm{pH}$ 9). Following a $1 \mathrm{~h}$ of incubation at room temperature, the reaction mixture was applied to a Sephadex G-25 column (Sigma) in order to separate the biotinylated toxins from free biotin. The toxin was eluted with sodium bicarbonate buffer. The fractions containing biotinylated ICPs were identified by dot blot analysis. $1 \mu \mathrm{L}$ of fraction was spotted onto a nitrocellulose membrane and incubated with streptavidin-alkaline phosphatase conjugate (diluted 1/300 in Tris-saline-Triton buffer (TST: $10 \mathrm{mM}$ Tris, $150 \mathrm{mM} \mathrm{NaCl}$, and $0.1 \%$ Triton X-100; pH 7.6)) for $1 \mathrm{~h}$. Biotinylated delta-endotoxins was visualized by incubation with an alkaline phosphatase substrate solution (1.75 mg of 5bromo-4-chloro-3-indolyl phosphate and $2.5 \mathrm{mg}$ of nitroblue tetrazolium in $10 \mathrm{~mL}$ of buffer containing $100 \mathrm{mM}$ Tris, $100 \mathrm{mM} \mathrm{NaCl}$, and $\left.5 \mathrm{mM} \mathrm{MgCl}_{2} ; \mathrm{pH} 9.5\right)$. The concentration of biotinylated delta-endotoxins was measured as described by Bradford [52] using BSA as a standard. The purity and integrity of biotinylated delta-endotoxins were checked by SDS-PAGE analysis followed by electroblotting onto a nitrocellulose membrane (Sigma) in a $0.5 \mathrm{x}$ Towbin buffer (12.5 mM Tris, 96 mM glycine; pH 8.3 with $10 \%$ methanol). Blotted membranes were developed using the same technique for dot-blot.

2.4. Histological Sections. Midguts of fifth instar larvae $\left(\mathrm{L}_{5}\right)$ of A. gemmatalis were dissected and fixed in Bouin Hollande $10 \%$ sublimate [57] for $24 \mathrm{~h}$, washed for $12 \mathrm{~h}$ in distilled water, and dehydrated with a series of ethanol baths (once at $70 \%$ ethanol, twice at $96 \%$ ethanol, and twice at $100 \%$ ethanol for $1 \mathrm{~h}$ each). The tissues were then infiltrated in mixedbaths (50\% ethanol: $50 \%$ toluol, $50 \%$ toluol: $50 \%$ paraplast) and twice impregnated with $100 \%$ paraplast before being embedded at $58^{\circ} \mathrm{C}$. Finally, the paraplast was hardened at $4^{\circ} \mathrm{C}$ $[27,56]$. Longitudinal sections, $7 \mu \mathrm{m}$ thick, were cut with a microtome and were placed on mounting glasses previously coated with a $10 \%$ poly-l-lysine section (Sigma).

2.5. In Vitro Binding of ICPs on Tissue Sections. In vitro detection of toxin binding was studied on tissue sections from isolated guts of untreated larvae. Tissue sections were deparaffinized and dehydrated with successive incubations: twice for $5 \mathrm{~min}$ with $100 \%$ toluol, three times for $3 \mathrm{~min}$ with $100 \%$ ethanol. The sections were washed with distilled $\mathrm{H}_{2} \mathrm{O}$ for $1 \mathrm{~min}$, treated with lugol $\left(0.5 \% \mathrm{I}_{2}\right.$ in $\left.\mathrm{H}_{2} \mathrm{O}\right)$, in order to remove $\mathrm{HgCl}_{2}$ (Aldrich), and subsequently immersed for $2 \mathrm{~min}$ in a $5 \% \mathrm{Na}_{2} \mathrm{~S}_{2} \mathrm{O}_{5}$ solution. After washing the tissues with distilled water for $1 \mathrm{~min}$, they were equilibrated in TST buffer for $5 \mathrm{~min}$. Prior to the incubation with toxin, the sections were treated with a blocking solution (1\% blocking reagent (Boehringer) in a TST buffer) in order to inhibit nonspecific binding.

The tissue sections were then incubated with 1.5 to $6 \mu \mathrm{g}$ of biotinylated toxins (CrylAa, CrylAc, CrylBa, CrylDa, CrylEa, and Cry2Aa) in the TST-buffer for $1 \mathrm{~h}$. Following a washing step with the TST-buffer, the tissues were covered with $300 \mu \mathrm{L}$ of streptavidin-alkaline phosphatase conjugate (Amersham) diluted 1/300 in TST-buffer. Following a $1 \mathrm{~h}$ incubation period, unbound streptavidin-enzyme conjugate was removed by washing with the TST-buffer and the bound toxin was finally visualized by incubation with an alkaline phosphatase substrate solution $(1.75 \mathrm{mg}$ of 5-bromo4-chloro-3-indolyl phosphate and $2.5 \mathrm{mg}$ of nitroblue tetrazolium in $10 \mathrm{~mL}$ of buffer containing $100 \mathrm{mM}$ Tris, $100 \mathrm{mM}$ $\mathrm{NaCl}$, and $5 \mathrm{mM} \mathrm{MgCl} ; \mathrm{pH} 9.5)$ or a peroxidase substrate (0.01\% 3,34-diaminobenzidine, $0.003 \% \mathrm{H}_{2} \mathrm{O}_{2}$ in $50 \mathrm{mM}$ Tris; $\mathrm{pH}$ 7.6). The reaction was stopped by transferring the samples to the TST buffer. Finally, in order to preserve the stained sections, the tissues were dehydrated and mounted with Clearium medium.

Negative controls were performed by omission of toxins or biotinylated toxins or enzyme-conjugated streptavidin. Staining was not observed when individual steps were omitted.

\section{Results}

3.1. Toxicity of ICPs on A. gemmatalis Larvae. The deltaendotoxins tested purity and integrity were evaluated in SDS-PAGE according to Figure 1. The data of the bioassays showed that five ICPs were toxic against larvae of 2 nd instar $A$. gemmatalis. In these bioassays, after 48 hours of treatments $\left(3 \cdot 10^{7}\right.$ cells $\left./ \mathrm{mL}\right)$, the strains $B$. thuringiensis dendrolimus HD37 (and from B. thuringiensis thuringiensis recombinant strain 407-pHT408), B. thuringiensis kurstaki HD73, B. thuringiensis thuringiensis 4412, B. thuringiensis aizawai HD68, and B. thuringiensis darmstadiensis HD146 caused $80 \%$ mortality corrected. However, the Cry2Aa strain produced by a recombinant $B$. thuringiensis strain expressing the cry $2 \mathrm{Aa}$ gene from $B$. thuringiensis kurstaki $\mathrm{HD}-1$ was not pathogenic against the population of the target species tested when compared to the control (100 $\mu \mathrm{L}$ of PBS).

In assays with purified ICPs, the following results were observed: (i) the strains $B$. thuringiensis dendrolimus HD37 (and from B. thuringiensis thuringiensis recombinant strain 407-pHT408), B. thuringiensis kurstaki HD73, and B. thuringiensis thuringiensis 4412 caused $90 \%$ mortality race in 48 hours after treatment application; (ii) the strains $B$. thuringiensis aizawai HD68, B. thuringiensis darmstadiensis HD146 caused $85 \%$ and $65 \%$ mortality, respectively, over a period between 144 and 168 hours after application of the proteins; and (iii) the recombinant $B$. thuringiensis strain expressing the cry2Aa gene from $B$. thuringiensis kurstaki HD-1 showed no significant mortality compared to the control (100 $\mu \mathrm{L}$ of PBS). 


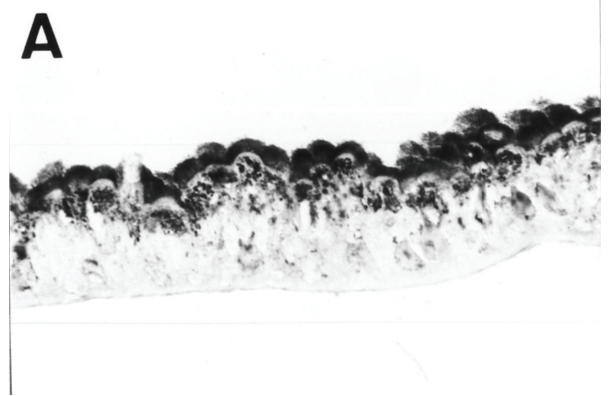

(a)

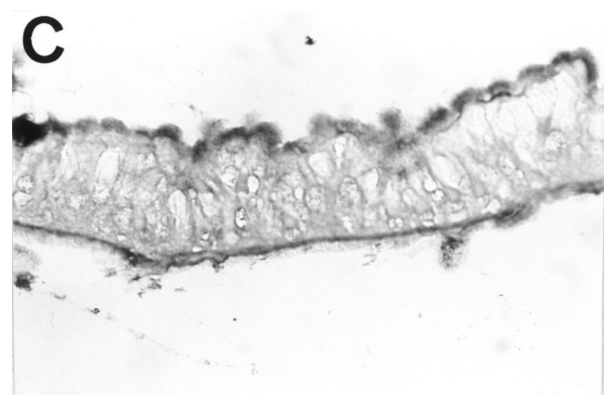

(c)

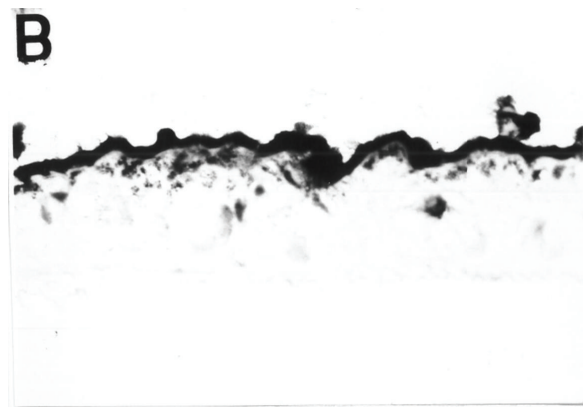

(b)

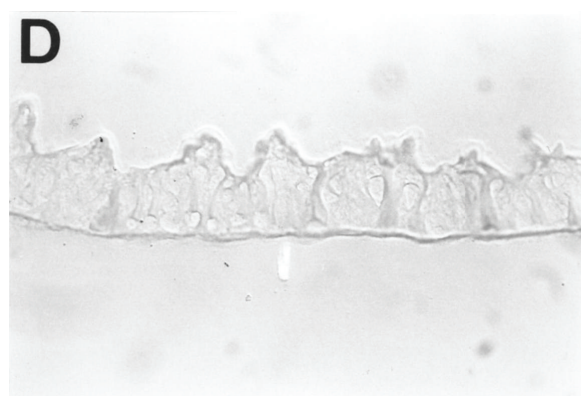

(d)

Figure 2: Detection of in vitro bound biotinylated ICPs on A. gemmatalis guts tissue: CrylAa (a), CrylAc (b), and CrylBa (c). Negative control (d) when tissue sections were incubated with the biotinylated ICPs (e.g., CrylAa) and omission of AP-conjugated streptavidin or when tissue section were incubated with the AP-conjugated streptavidin and omission of biotinylated ICPs. Light micrograph obtained with Nomarski differential interference contrast illumination.

In vivo assays to determine the median lethal concentration $\left(\mathrm{LC}_{50}\right)$ native toxins (ICPs) were used, which was obtained from the purified crystals. In these assays, three ICPs were applied (CrylAa: B. thuringiensis dendrolimus HD37 or from $B$. thuringiensis thuringiensis recombinant strain 407-pHT408; CrylAc: B. thuringiensis kurstaki HD73; and CrylBa: B. thuringiensis thuringiensis 4412) which caused the greatest acute toxicity in preliminary tests. The $\mathrm{LC}_{50}$ of native toxins CrylAa, CrylAc, and CrylBa was less than $0.1 \mu \mathrm{g} / \mathrm{larvae}$ on the seventh day after the treatment when compared to the corresponding positive control (strain $B$. thuringiensis kurstaki $\mathrm{HD} 1$ ) whose $\mathrm{LC}_{50}$ equivalent to $0.082 \mu \mathrm{g} /$ larvae $(0.056-0.105)$ on the fifth day after the treatment.

3.2. ICPs Receptors Binding Sites to A. gemmatalis Larvae Tissue Sections. The three biotinylated toxins (CrylAa, CrylAc, and CrylBa) with greater lethal effect on larvae of 2 nd instar A. gemmatalis were studied on midgut tissue sections from untreated larvae. Bound biotinylated ICP was visualized using and streptavidin-mediated detection techniques.

Incubation with CrylAa (Figure 2(a)) and CrylAc (Figure 2(b)) resulted in very intense staining of the brush border along the whole length of the midgut. Staining due to binding of CrylBa (Figure 2(c)) was also intense but not evenly distributed throughout the midgut. No labeling was observed with control samples to the brush border membrane (Figure 2(d)).

\section{Discussion}

The Cryl gene of B. thuringiensis ICPs were a great promise for the control of lepidopteran pests on soybean, either as a microbial insecticide or by being genetically engineering into the soybean plant [58]. In this study, we have analysed toxicity and binding of six ICPs to larvae of $A$. Bioassays using trypsin-activated ICPs, and second instar of A. gemmatalis indicated that among the six proteins tested, CrylAa, CrylAc, and CrylBa were most active on this insect. CrylDa and CrylEa were less active while Cry2Aa was essentially not active.

Also in search of biological control of the velvetbean caterpillar, the pathogenicity of twelve $B$. thuringiensis isolates was tested against A. gemmatalis [59]. Those authors performed a series of bioassays by feeding third instar larvae of $A$. gemmatalis with artificial diets containing the $B$. thuringiensis spore-crystal complex $\left(3 \cdot 10^{8}\right.$ cells $\left./ \mathrm{mL}\right)$, where four new isolates (U87-2, U98-1, U98-4, and IP01) showed that larval mortality of A. gemmatalis similar or greater as standard strain (B. thuringiensis kurstaki HD1-Dipel), and the PCR technique was used to amplify DNA fragments related to the known $c r y 1$ genes. The toxic $B$. thuringiensis isolates also exhibited an expected protein profile when total protein extracts were evaluated by SDS-PAGE [59], confirming that the Cryl toxins are toxic potential for the species studied in our work (velvetbean caterpillar).

However, another new B. thuringiensis (Bt117-4) isolate that amplifies fragments corresponding to $c r y 2$ and $\operatorname{cry} 9$ 
genes, which synthesize protein fragments of equivalent to 130,90 , and $45 \mathrm{kDa}$ [58]. The transmission electron microscopy revealed the presence of protein crystals and the $\mathrm{CL}_{50}$ with Cry-purified proteins corresponded to $0.195 \mu \mathrm{g} /$ larvae of the second instar of A. gemmatalis, whose data were very similar to this paper.

In order to study the interaction of ICPs with the digestive tract of A. gemmatalis, we have studied in vitro receptors binding of biotinylated ICPs to midgut tissue sections of healthy larvae. In this way, these results generally correlate with levels of toxicity of the different ICPs. For instance, the most toxic proteins, CrylAa and CrylAc, bind strongly in vitro and result in strong detection staining signals. In contrast, CrylBa was less active than the above mentioned Cryl ICPs, displaying less intense in vitro binding to tissue sections, which render the affinity for this toxin even lower than in the insect midgut. The results from our receptors binding studies on tissue slides are in agreement with the observations from binding experiments with radiolabeled toxins on brush border membrane vesicles from C. suppressalis $[18,20]$. Fiuza et al. [18] demonstrated that both CrylAa and CrylAc bind with high affinity whereas CrylBa binds with somewhat lower affinity.

On the basis of the general correlation between toxicity and receptors binding to the brush border observed in this study, it may be suggested to use these in vitro binding detection methods as a means of screening in order to quickly select $B$. thuringiensis ICPs which could have an in vivo effect on Lepidoptera larva and other insect species, as indicated by Denolf et al. [26, 56]. These methods, however, are obviously of a qualitative rather than a quantitative nature, since among ICPs with significant insecticidal activity there is no clear correlation between staining intensity and toxicity. This lack of a quantitative correlation has been observed previously for O. nubilalis [26]. Likewise, in many cases, there is no quantitative correlation between binding parameters such as binding affinity or receptor site concentration and toxicity. Clearly, if screening by binding is performed, the ICPs that show binding to tissue of the target insect need to be tested in bioassays to confirm biological activity.

\section{Conclusion}

The present study shows that $B$. thuringiensis ICPs which bind to receptor sites in the midgut of the target insect should be evaluated in vivo to estimate the lethal effect, but the toxins that do not have receptors in the guts need not be tested in bioassays. In order to control A. gemmatalis larvae, it is possible to use commercial $B$. thuringiensis products containing strains producing ICPs toxic against this species. A helpful alternative would be to express $B$. thuringiensis genes encoding ICPs active against $A$. gemmatalis in soybean plants in order to obtain plants that are resistant to this pest. Currently, several studies confirmed the successful use of soy Bt, for example, Stewart et al. [60], these authors used somatic embryos of Jack, a Glycine max Merrill cultivar, were transformed using microprojectile bombardment with a synthetic Bacillus thuringiensis insecticidal crystal protein gene (crylAc) driven by the $35 \mathrm{~s}$ promoter and linked to the HPH gene. In detached-leaf bioassays, plants with an intact copy of the Bt gene, and to a lesser extent those with the rearranged copy, were protected from damage from Helicoverpa zea, Pseudoplusia includens, Heliothis virescens, and Anticarsia gemmatalis. Corn earworm produced less than 3\% defoliation on transgenic plants compared with $20 \%$ on the lepidopteran-resistant breeding line CatlR81-296 and more than $40 \%$ on susceptible cultivars. According to our results, it would be advisable to use ICPs CrylAa, CrylAc, or CrylBa.

\section{Conflict of Interests}

The authors declare no conflict of interests.

\section{Acknowledgments}

The authors are especially grateful to Dr. Jeroen Van Rie (PGS) and Dr. Jean-François Charles (Institute Pasteur) for their advices. they are also grateful to Emmanuel Guiderdoni and Jacques Escoute (CIRAD) for their collaboration and thank also FAPERGS and CNPq (Brazil) for their financial help with this work.

\section{References}

[1] R. A. de Maagd, D. Bosch, and W. Stiekema, "Bacillus thuringiensis toxin-mediated insect resistance in plants," Trends in Plant Science, vol. 4, no. 1, pp. 9-13, 1999.

[2] L. A. Lacey and M. S. Goettel, "Current developments in microbial control of insect pests and prospects for the early $21 \mathrm{st}$ century," Entomophaga, vol. 40, no. 1, pp. 3-27, 1995.

[3] B. Lambert and M. Peferoen, "Insecticidal promise of Bacillus thuringiensis. Facts and mysteries about a successful biopesticide," Bioscience, vol. 42, pp. 112-122, 1992.

[4] S. S. Gill, E. A. Cowles, and P. V. Pietrantonio, "The mode of action of Bacillus thuringiensis endotoxins," Annual Review of Entomology, vol. 37, no. 1, pp. 615-636, 1992.

[5] S. S. Gill, "Mechanism of action of Bacillus thuringiensis toxins," Memórias do Instituto Oswaldo Cruz, vol. 90, no. 1, pp. 69-74, 1995.

[6] H. Hofte, J. van Rie, S. Jansens, A. van Houtven, H. Vanderbruggen, and M. Vaeck, "Monoclonal antibody analysis and insecticidal spectrum of three types of lepidopteran-specific insecticidal crystal proteins of Bacillus thuringiensis," Applied and Environmental Microbiology, vol. 54, no. 8, pp. 2010-2017, 1988.

[7] M. Miyasono, S. Inagaki, M. Yamamoto et al., "Enhancement of delta-endotoxin activity by toxin-free spore of Bacillus thuringiensis against the diamondback moth, Plutella xylostella," Journal of Invertebrate Pathology, vol. 63, no. 1, pp. 111-112, 1994.

[8] A. Bravo, "Phylogenetic relationships of Bacillus thuringiensis $\delta$-endotoxin family proteins and their functional domains," Journal of Bacteriology, vol. 179, no. 9, pp. 2793-2801, 1997.

[9] E. Schnepf, N. Crickmore, J. van Rie et al., "Bacillus thuringiensis and its pesticidal crystal proteins," Microbiology and Molecular Biology Reviews, vol. 62, no. 3, pp. 775-806, 1998. 
[10] A. I. Aronson, "The two faces of Bacillus thuringiensis: insecticidal proteins and post-exponential survival," Molecular Microbiology, vol. 7, no. 4, pp. 489-496, 1993.

[11] A. Aronson, "The protoxin composition of Bacillus thuringiensis insecticidal inclusions affects solubility and toxicity," Applied and Environmental Microbiology, vol. 61, no. 11, pp. 4057-4060, 1995.

[12] D. U. Cheng and K. W. Nickerson, "The Bacillus thuringiensis insecticidal toxin binds biotin-containing proteins," Applied and Environmental Microbiology, vol. 62, no. 8, pp. 2932-2939, 1996.

[13] B. Lambert, L. Buysse, C. Decock et al., "A Bacillus thuringiensis insecticidal crystal protein with a high activity against members of the family noctuidae," Applied and Environmental Microbiology, vol. 62, no. 1, pp. 80-86, 1996.

[14] H. Hofte and H. R. Whiteley, "Insecticidal crystal proteins of Bacillus thuringiensis," Microbiological Reviews, vol. 53, no. 2, pp. 242-255, 1989.

[15] J. A. Baum and T. Malvar, "Regulation of insecticidal crystal protein production in Bacillus thuringiensis," Molecular Microbiology, vol. 18, no. 1, pp. 1-12, 1995.

[16] J. A. Baum, M. Kakefuda, and C. Gawron-Burke, "Engineering Bacillus thuringiensis bioinsecticides with an indigenous sitespecific recombination system," Applied and Environmental Microbiology, vol. 62, no. 12, pp. 4367-4373, 1996.

[17] U. Estada and J. Ferre, "Binding of insecticidal crystal proteins of Bacillus thuringiensis to the midgut brush border of the cabbage looper, Trichoplusia ni (Hübner) (Lepidoptera: Noctuidae), and selection for resistance to one of the crystal proteins," Applied and Environmental Microbiology, vol. 60, no. 10, pp. 3840-3846, 1994.

[18] L.-M. Fiuza, C. Nielsen-Leroux, E. Goze, R. Frutos, and J.-F. Charles, "Binding of Bacillus thuringiensis Cryl toxins to the midgut brush border membrane vesicles of Chilo suppressalis (Lepidoptera: Pyralidae): evidence of shared binding sites," Applied and Environmental Microbiology, vol. 62, no. 5, pp. 1544-1549, 1996.

[19] C. Hofmann, H. Vanderbruggen, H. Hofte, J. van Rie, S. Jansens, and H. van Mellaert, "Specificity of Bacillus thuringiensis $\delta$ endotoxins is correlated with the presence of high-affinity binding sites in the brush border membrane of target insect midguts," Proceedings of the National Academy of Sciences of the United States of America, vol. 85, no. 21, pp. 7844-7848, 1988.

[20] M. K. Lee, R. M. Aguda, M. B. Cohen, F. L. Gould, and D. H. Dean, "Determination of binding of Bacillus thuringiensis $\delta$ endotoxin receptors to rice stem borer midguts," Applied and Environmental Microbiology, vol. 63, no. 4, pp. 1453-1459, 1997.

[21] J. van Rie, S. Jansens, H. Hofte, D. Degheele, and H. van Mellaert, "Specificity of Bacillus thuringiensis $\delta$-endotoxins. Importance of specific receptors on the brush border membrane of the mid-gut of target insects," European Journal of Biochemistry, vol. 186, no. 1-2, pp. 239-247, 1989.

[22] B. H. Knowles, P. J. K. Knight, and D. J. Ellar, "N-acetyl galactosamine is part of the receptor in insect gut epithelia that recognizes an insecticidal protein from Bacillus thuringiensis," Proceedings of the Royal Society B, vol. 245, no. 1312, pp. 31-35, 1991.

[23] B. H. Knowles, "Mechanism of action of Bacillus thuringiensis insecticidal delta-endotoxins," Advances in Insect Physiology, vol. 24, pp. 275-308, 1994.
[24] S. L. Slatin, C. K. Abrams, and L. English, "Delta-endotoxins form cation-selective channels in planar lipid bilayers," Biochemical and Biophysical Research Communications, vol. 169, no. 2, pp. 765-772, 1990.

[25] A. Bravo, K. Hendrickx, S. Jansens, and M. Peferoen, "Immunocytochemical analysis of specific binding of Bacillus thuringiensis insecticidal crystal proteins to lepidopteran and coleopteran mudgut membranes," Journal of Invertebrate Pathology, vol. 60, no. 3, pp. 247-253, 1992.

[26] P. Denolf, S. Jansens, M. Peferoen, D. Degheele, and J. van Rie, "Two different Bacillus thuringiensis delta-endotoxin receptors in the midgut brush border membrane of the European corn borer, Ostrinia nubilalis (Hübner) (Lepidoptera: Pyralidae)," Applied and Environmental Microbiology, vol. 59, no. 6, pp. 1828-1837, 1993.

[27] A. Bravo, S. Jansens, and M. Peferoen, "Immunocytochemical localization of Bacillus thuringiensis insecticidal crystal proteins in intoxicated insects," Journal of Invertebrate Pathology, vol. 60, no. 3, pp. 237-246, 1992.

[28] A. Boets, S. Jansens, P. Denolf, M. Peferoen, D. Degheele, and J. van Rie, "Sequential observations of toxin distribution and histopathological effects of CryIIIA in the gut of intoxicated Leptinotarsa decemlineata larvae," in Proceedings of the 27th Annual Meeting of the Society for Invertebrate Pathology, p. 377, 1994.

[29] S. F. Garczynski, J. W. Crim, and M. J. Adang, "Identification of putative insect brush border membrane-binding molecules specific to Bacillus thuringiensis $\delta$-endotoxin by protein blot analysis," Applied and Environmental Microbiology, vol. 57, no. 10, pp. 2816-2820, 1991.

[30] P. J. K. Knight, N. Crickmore, and D. J. Ellar, “The receptor for Bacillus thuringiensis CrylA(c) delta-endotoxin in the brush border membrane of the lepidopteran Manduca sexta is aminopeptidase N," Molecular Microbiology, vol. 11, no. 3, pp. 429-436, 1994.

[31] S. S. Gill, E. A. Cowles, and V. Francis, "Identification, isolation, and cloning of a Bacillus thuringiensis CryIAc toxin-binding protein from the midgut of the lepidopteran insect Heliothis virescens," Journal of Biological Chemistry, vol. 270, no. 45, pp. 27277-27282, 1995.

[32] M. K. Lee, T. H. You, B. A. Young, J. A. Cotrill, A. P. Valaitis, and D. H. Dean, "Aminopeptidase N purified from gypsy moth brush border membrane vesicles is a specific receptor for Bacillus thuringiensis CryIAc toxin," Applied and Environmental Microbiology, vol. 62, no. 8, pp. 2845-2849, 1996.

[33] S. Sangadala, F. S. Walters, L. H. English, and M. J. Adang, "A mixture of Manduca sexta aminopeptidase and phosphatase enhances Bacillus thuringiensis insecticidal CryIA(c) toxin binding and ${ }^{86} \mathrm{Rb}^{+}-\mathrm{K}^{+}$efflux in vitro," Journal of Biological Chemistry, vol. 269, no. 13, pp. 10088-10092, 1994.

[34] A. P. Valaitis, M.-K. Lee, F. Rajamohan, and D. H. Dean, "Brush border membrane aminopeptidase- $\mathrm{N}$ in the midgut of the gypsy moth serves as the receptor for the CryIA(c) deltaendotoxin of Bacillus thuringiensis," Insect Biochemistry and Molecular Biology, vol. 25, no. 10, pp. 1143-1151, 1995.

[35] K. Yaoi, T. Kadotani, H. Kuwana et al., "Aminopeptidase N from Bombyx mori as a candidate for the receptor of Bacillus thuringiensis CrylAa toxin," European Journal of Biochemistry, vol. 246, no. 3, pp. 652-657, 1997.

[36] G. Hua, L. Masson, J. L. Jurat-Fuentes, G. Schwab, and M. J. Adang, "Binding analyses of Bacillus thuringiensis Cry $\delta$ endotoxins using brush border membrane vesicles of Ostrinia 
nubilalis," Applied and Environmental Microbiology, vol. 67, no. 2, pp. 872-879, 2001.

[37] R. K. Vadlamudi, E. Weber, I. Ji, T. H. Ji, and L. A. Bulla Jr., "Cloning and expression of a receptor for an insecticidal toxin of Bacillus thuringiensis," Journal of Biological Chemistry, vol. 270, no. 10, pp. 5490-5494, 1995.

[38] O. Ravoahangimalala, J.-F. Charles, and J. Schoeller-Raccaud, "Immunological localization of Bacillus thuringiensis serovar israelensis toxins in midgut cells of intoxicated Anopheles gambiae larvae (Diptera: Culicidae)," Research in Microbiology, vol. 144, no. 4, pp. 271-278, 1993.

[39] J. van Rie, S. Jansens, H. Hofte, D. Degheele, and H. van Mellaert, "Receptors on the brush border membrane of the insect midgut as determinants of the specificity of Bacillus thuringiensis delta-endotoxins," Applied and Environmental Microbiology, vol. 56, no. 5, pp. 1378-1385, 1990.

[40] M. Wolfersberger, "Specificity and mode of action of Bacillus thuringiensisinsecticidal crystal proteins toxic to lepidopteran larvae: recent insights from studies utilizing midgut brush border membrane vesicles," in Proceedings of the 5th International Colloquium on Invertebrate Pathology and Microbial Control, pp. 278-282, Adelaide, Australia, August 1990.

[41] Y. Liang, S. S. Patel, and D. H. Dean, "Irreversible binding kinetics of Bacillus thuringiensis CryIA $\delta$ - endotoxins to gypsy moth brush border membrane vesicles is directly correlated to toxicity," Journal of Biological Chemistry, vol. 270, no. 42, pp. 24719-24724, 1995.

[42] J. Ferre, M. D. Real, J. van Rie, S. Jansens, and M. Peferoen, "Resistance to the Bacillus thuringiensis bioinsecticide in a field population of Plutella xylostella is due to a change in a midgut membrane receptor," Proceedings of the National Academy of Sciences of the United States of America, vol. 88, no. 12, pp. 51195123, 1991.

[43] J. Ferre, B. Escriche, Y. Bel, and J. van Rie, "Biochemistry and genetics of insect resistance to Bacillus thuringiensis insecticidal crystal proteins," FEMS Microbiology Letters, vol. 132, no. 1-2, pp. $1-7,1995$.

[44] L. Masson, Y.-J. Lu, A. Mazza, R. Brousseau, and M. J. Adang, "The CryIA(c) receptor purified from Manduca sexta displays multiple specificities," Journal of Biological Chemistry, vol. 270, no. 35, pp. 20309-20315, 1995.

[45] A. R. Panizzi and B. S. Corrêa-Ferreira, "Dynamics in the insect fauna adaptation to soybean in the tropics," Trends Entomology, vol. 1, pp. 71-88, 1997.

[46] S. M. Levy, A. M. F. Falleiros, E. A. Gregório, N. R. Arrebola, and L. A. Toledo, "The larval midgut of anticarsia gemmatalis (Hübner) (lepidoptera: Noctuidae): light and electron microscopy studies of the epithelial cells," Brazilian Journal of Biology, vol. 64, no. 3B, pp. 633-638, 2004.

[47] D. Gallo, O. Nakano, S. S. Neto et al., Entomologia agrícola, Fundação de Estudos Agrários Luiz de Queiroz, Piracicaba, Brazil, 2002.

[48] L. Morales, F. Moscardi, J. G. Kastelic, D. R. Sosa-Gómez, F. E. Paro, and I. L. Soldório, "Suscetibilidade de Anticarsia gemmatalis Hübner e Chrysodeixis includes (Walker) (Lepidoptera: Noctuidae), a Bacillus thuringiensis (Berliner)," Anais da Sociedade Entomológica do Brasil, vol. 24, pp. 593-598, 1995.

[49] F. Moscardi and Carvalho, "Consumo e utilização de soja por Anticarsia gemmatalis Hüb. (Lepidoptera: Noctuidae) infectada, em diferentes estádios larvais, por seu vírus de poliedrose nuclear," Anais da Sociedade Entomológica do Brasil, vol. 22, pp. 267-280, 1993.
[50] J. Mahillon and J. Delcour, "A convenient procedure for the preparation of highly purified parasporal crystals of Bacillus thuringiensis," Journal of Microbiological Methods, vol. 3, no. 2, pp. 69-76, 1984

[51] U. K. Laemmli, "Cleavage of structural proteins during the assembly of the head of bacteriophage T4," Nature, vol. 227, no. 5259, pp. 680-685, 1970.

[52] M. M. Bradford, "A rapid and sensitive method for the quantitation of microgram quantities of protein utilizing the principle of protein dye binding," Analytical Biochemistry, vol. 72, no. 1-2, pp. 248-254, 1976.

[53] G. L. Greene, N. C. Leppla, and W. A. Dickerson, "Velvetbean caterpillar: a rearing procedure and artificial medium," Journal of Economic Entomology, vol. 69, no. 4, pp. 487-488, 1976.

[54] M. L. Haddad, "Utilização do Polo-PC para análise de Probit," in Controle Microbiano de Insetos, S. B. Alves, Ed., pp. 21-38, Fundação de Estudos Agrários Luiz de Queiroz, Piracicaba, Brazil, 2nd edition, 1998.

[55] E. A. Bayer and M. Wilchek, "Protein biotinylation," Methods in Enzymology, vol. 184, pp. 138-160, 1990.

[56] P. Denolf, S. Jansens, S. van Houdt, M. Peferoen, D. Degheele, and J. van Rie, "Biotinylation of Bacillus thuringiensis insecticidal crystal proteins," Applied and Environmental Microbiology, vol. 59, no. 6, pp. 1821-1827, 1993.

[57] P. Brandtzaeg, "Tissue preparation methods for immunocytochemistry," in Techniques in Immunocytochemistry, G. Bullock and P. Petruz, Eds., pp. 49-51, Academic Press, London, UK, 1982.

[58] L. M. Fiuza, R. Schünemann, L. M. N. Pinto, and M. H. B. Zanettini, "Two new Brazilian isolates of Bacillus thuringiensis toxic to Anticarsia gemmatalis (Lepidoptera: Noctuidae)," Brazilian Journal of Biology, vol. 72, no. 2, pp. 363-369, 2012.

[59] V. L. Bobrowski, G. Pasquali, M. H. Bodanese-Zanettini, and L. M. Fiuza, "Detection of Cryl genes in Bacillus thuringiensis isolates from south of Brazil and activity against Anticarsia gemmatalis (Lepidoptera: Noctuidae)," Brazilian Journal of Microbiology, vol. 32, no. 2, pp. 105-109, 2001.

[60] C. N. Stewart Jr., M. J. Adang, J. N. All et al., "Genetic transformation, recovery, and characterization of fertile soybean transgenic for a synthetic Bacillus thuringiensis cryIAc gene," Plant Physiology, vol. 112, no. 1, pp. 121-129, 1996. 

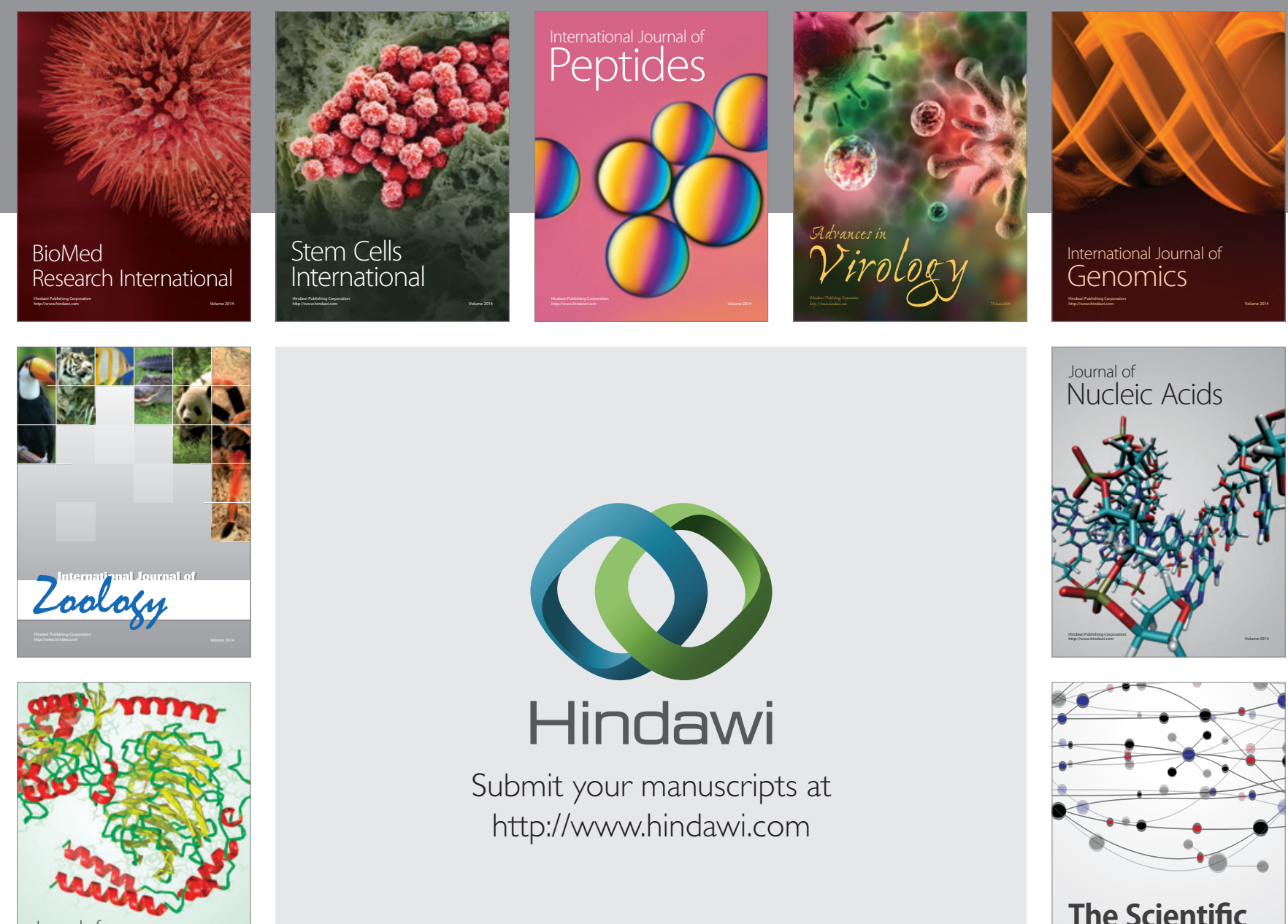

Submit your manuscripts at

http://www.hindawi.com

Journal of
Signal Transduction
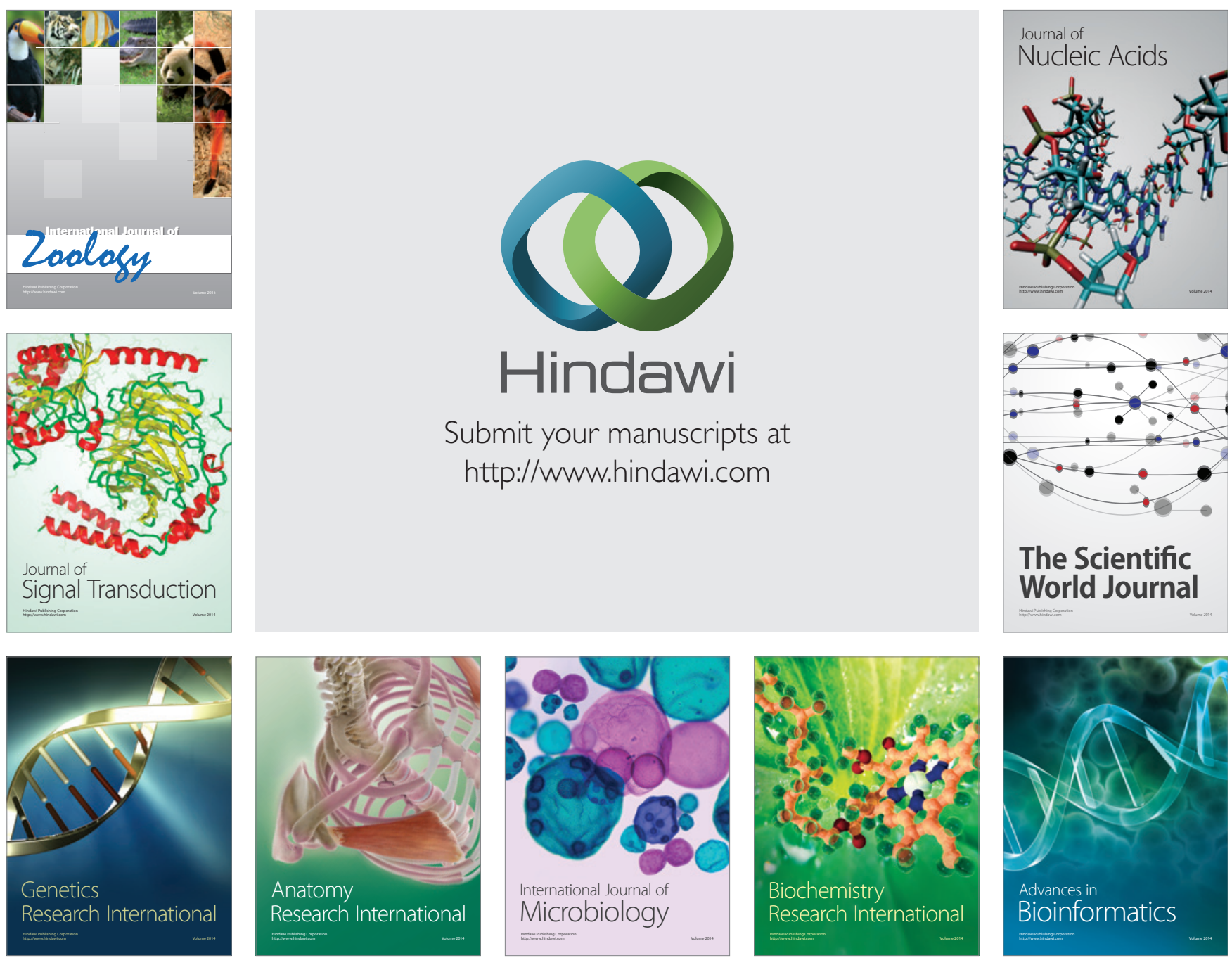

The Scientific World Journal
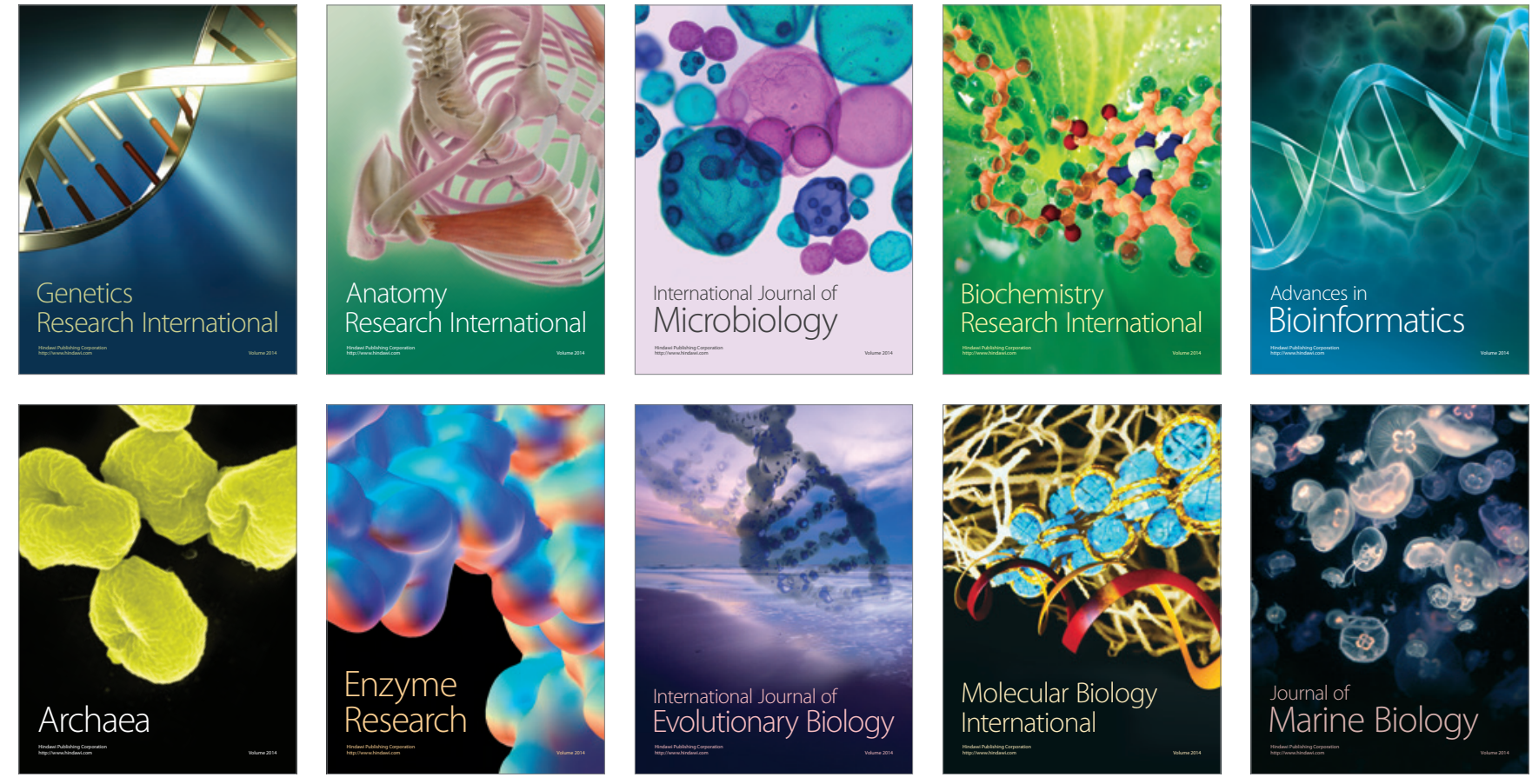